\title{
Українсько-єврейські взаємини крізь призму постаті Івана Франка
}

\author{
Oxana Blaškiv (Siedlce)
}

Mnich, Roman: Ivan Franko i jevrejstvo. Siedlce: Instytut Kultury Regionalnej i Badań Literackich - Doktoratskolleg Galizien Wien, 2018. 525 s. ISBN 978-83-64884-14-6.

Поруч 3 дослідженням спадщини Дмитра Чижевського (1894-1977), Яна Амоса Коменського (1592-1670), російської літератури Срібного віку та теорії символу на тлі філософії та теорії літератури ХХ століття, тема діалогу єврейства із слов'янським світом уже тривалий час є однією із провідних у науковому доробку Романа Мниха, працівника Варшавського університету, а донедавна - директора Інституту неофілології та інтердисциплінарних досліджень Природничо-гуманістичного університету в Сєдльцах (Польща). Про багаторічне зацікавлення цією проблематикою свідчать численні розвідки, статті, монографії автора, серед яких Дрогобичанин Бруно Шульи (Дрогобич, 2006). Значним є також і організаціно-науковий внесок P. Мниха, у доробку якого наукові збірники, присвячені слов'янсько-єврейському діалогу, що виходили в серії Colloquia Judaica (20112016) при Інституті полоністики Природничо-гуманістичного університету в Сєдльцах (співредактор - Рената Тарасюк), колективна монографія Galicia, Bukovina and Other Borderlands in Eastern and Central Europe: Essays on Interethnic Contacts and Multiculturalism (Epyсалим-Сєдльце, 2013, співредактори - Рената Тарасюк та Вольф Москович) колективна монографія Galicja 1916: plus/minus dziesięć lat (przestrzenie dyskursów: historia, literatury, kultury, jezyki) (Сєдльце, 2018, співредактор - Анджей Борковский).

Водночас, попри широту зацікавлень юдейською тематикою, впродовж років увагу Романа Мниха займає постать Івана Франка та його стосунки $з$ єврейством. Показовою у цьому зв'язку є його німецькомовна моно- графія Ivan Franko im Kontext mit Theodor Herzl und Martin Buber: Antisemitismus und Philosemitismus in Ostgalizien 1886-1916 (Констанц, 2012). Ця книга Р. Мниха викликала значний резонанс в наукових колах та стала поштовхом до організації конференції «Іван Франко і єврейське питання у Галичині: міжкультурні зустрічі й динаміка у творчості українського письменника» (24-25 жовтня 2013 року, Віденський університет). А поконференційна збірка текстів На перехресних стежках. Іван Франко та єврейське питання у Галичині (упорядники - Алоїза Вольдана і Олафа Терпіца, український переклад - Київ, 2016), до створення якої доклалися вчені з різних країн світу, викликала в Україні бурхливу громадську дискусію ${ }^{1}$.

У цьому контексті, рецензована книжка Р. Мниха Іван Франко та єврейство, опублікована у 2018 році у науковому видавництві Інституту регіональної культури та міждисциплінарних досліджень ім. Францішка Карпінського - це певний підсумок багаторічної праці автора над надзвиачйно складною науковою проблемою. Дане дослідження орієнтоване, передовсім, на україномовну славістичну аудиторію вчених-компаративістів та ареалознавців.

Як відомо, наприкінці XIX - на початку XX століття Галичина була особливим багатоетнічним та полікультурним регіоном, дослідження якого впродовж останніх десятиліть значно поглибилося завдяки українським та

1 MNICH, Roman: Ne tak tii vorohy, jak ti patrioty. Krytyka (Kyiv) 21, 2017, č. 1-2. Dostup 29.10.2019. <https:// krytyka.com/ua/articles/ne-tak-tiyi-vorohy-yak-tipatrioty>. 
закордонним науковим проектам. А однією 3 центральних постатей тогочасної Галичини була постать Івана Франка, чиє життя і творчість привертає увагу дослідників по обидва боки сучасного кордону України. Знаковим $\varepsilon$ те, що особистість українського Каменяра цікавить не лише істориків, філософів, літературознавців та культурологів. Доволі часто ім'я Франка фігурує у громадських дискусіях, ініційованих представниками різних політичних сил, котрі експлуатують його образ у своїх цілях (щоправда Франко не єдиний класик літератури, життя і творчість якого час від часу сколихує громадськість - такі хвилі спекулятивного інтересу накривають то Т. Шевченка, то Л. Українку, то О. Кобилянську...). Зазвичай подібні дискусії базуються на безвідповідальному наведенні цитат, що вириваються з контексту або тлумачаться без розуміння історичних та особистісних обставин. На думку Р. Мниха, це складає «дуже своєрідну рису власне українського шляху розвитку...через специфіку власної української історії» (с. 26), що водночас не заперечує певної незрілості суспільства загалом. Саме тому «франкознавство є вельми специфічною проблемою для сучасної української гуманітарної думки, а одночасно і проблемою українського суспільства взагалі» (с. 26). Правда й сама постать I. Франка, його непростий життєвий і творчий шлях дають багато приводів для маніпуляції зацікавленим сторонам. Впродовж життя його погляди неодноразово зазнавали змін, що дає можливість трактувати I. Франка одночасно як речника «ідеології польського селянства та єврейського пролетаріату» (с. 15), та служить добрим матеріалом для адаптації відповідних ідеологічних запитів.

Саме артикулюванню подібних проблем i розведенню понять, пов'язаних $з$ таким складним питанням як єврейство у контексті життя і творчої спадщини I. Франка, найперше покликана служити рецензована монографія. Адже особливо уважне прочитання творчості українського письменника набирає неабиякої ваги власне сьогодні, коли Фран- ка пов'язують не стільки з розвитком української літератури, скільки 3 «процес[ом] модернізації тодішнього українського суспільства, розділеного між двома імперіями, і народженням модерної української нації... що синхронно співпадало із виникненням сіонізму як політично зорієнтованої ідеології та аналогічними процесами в інших європейських країнах (Польщі, Чехії, Болгарії, тощо), а також у середовищі європейського єврейства» (с. 26). Проте, попри всю складність особистості I. Франка та часу у який він жив, актуальним є критичне осмислення його величезної й багатогранної спадщини з урахуванням історичного тла та суспільних контекстів.

Надзвичайно важливо, на думку Р. Мниха, чітко розмежовувати науковий дискурс від популярного чи політичного. Тому у Передмові до книжки автор подає детальну методологічну карту власного дослідження у якій зазначає, що у проблемі «Франко і єврейство» важливо розмежовувати три іпостасі Франка, у яких він проявляє себе у ставленні щодо: 1) конкретних євреїв, 2) галицького єврейства та єврейского питання в Галичині, 3) євреїв як народу в цілому, їх історії та культури. Відтак об'єктами дослідження Р. Мниха (тобто герменевтичного та історико-контекстуального прочитання текстів) стали відповідно: 1) художні твори I. Франка, 2) його кореспонденція, 3) публіцистика та 4) спогади сучасників про нього. Цьому відповідають чотири варіанти інтерпретації: художніх творів - відповідно до «розуміння художньої дійсності як дійсності фікційної (світ художній, а не реальний), у якій голос автора $є$ тільки одним із можливих голосів» (с. 13), публіцистичних творів - як ідеологічних конструктів, кореспонденції - як спроби історичної реконструкції, а спогадів - як деконструкції, яка «спрямована передусім на пошук у текстах спогадів такої інформації, котра $є$ безперечною, історично достовірною і може бути підтвердженою іншими джерелами» (с. 14). При цьому, стосовно розуміння спогадів, акцент робиться на: а) поста- 
ті автора спогадів, б) причини їх написання, та в) самій події, описаній в них. Тут зазначу, що яскравим прикладом такої деконструкції є спогади Василя Щурата про зустріч Івана Франка з Теодором Герцелем, подані автором у третьому розділі монографії (с. 140153). Окрему увагу Р. Мних звертає також на важливість залишатися в рамках наукового дискурсу, що рідко вдається сучасним дослідникам-франкознавцям. Відзначається також необхідність напрацювання вченими франкознавчої термінології, котра на сьогодні не завжди характеризується адекватністю (відповідністю сучасних термінів та понять щодо інтенції досліджуваних текстів I. Франка) та не завжди враховує «відмінності мови об'єкту дослідження і мови наукового дискурсу цього об'єкту» (с. 45).

Окремий розділ книжки автор присвячує єврейським дискурсам Івана Франка, підкреслюючи як своєрідність єврейського питання в Галичині кінця XIX століття (тема, що ще чекає на своїх неупереджених дослідників), так і специфіку самого I. Франка, котрий представляв свої міркування та вів дискусії одночасно трьома мовами - німецькою, польською й українською. Р. Мних наголошує, що «Іван Франко був тим українським автором, котрий найбільше і найвиразніше писав про українсько-єврейські відносини у їх історичній ретроспективі та перспективі» (с. 59). Узагальнюючи єврейську тематику та проблематику в спадщині Каменяра, автор виокремлює сім типів Франкового дискурсу: біографічний, епістолярний, публіцистичний, дискурс художньої прози, поетичний, фольклористичний та літературознавчий, ілюструючи кожен із них конкретними прикладами. Як слушно зауважує Р. Мних, поєднання такого спектру єврейської тематики у творчості однієї особи уже само собою є феноменом, тому не дивно, що ці дискурси часто переплітаються. У цьому контексті для порівняння авторського підходу у інтерпретації образів євреїв у творчості Франка слід звернути увагу на нещодавно видану украЇнською мовою монографію канадського вченого Мирослава Шкандрія, присвячену репрезентації єврея в українській літературі впродовж останніх двохсот років ${ }^{2}$.

3 перспективи літературознавства, найбільш цікавим все ж видаються зауваження Р. Мниха щодо літературознавчого дискурсу I. Франка. Пропри всю складність саме цього типу єврейських дискурсів Каменяра, вельми важливим є окреслення автором таких напрямків майбутніх досліджень як: інтертектуальність праць I. Франка у контексті творів еврейських авторів, єврейська тема в давній українській літературі, розвідки I. Франка про Талмуд, єврейська тема у дослідженнях про європейську та українську літературу XIX-XX століть. У підсумку автор виокремлює три найбільш пріоритетні теми досліджень у контексті проблематики «Франко і єврейство», а саме: 1) стосунки Франка з визначними діячами єврейської культури або тими євреями, що долучилися до творення польської чи австрійської культури, 2) єврейська тематика та проблематика у творчості Франка, та 3) біблійна образність, використана Франком для проекції на українську дійсність.

У розділі Семітизм та антисемітизм у Галичині кіния XIX - поч. XX століття P. Мних аналізує публіцистику I. Франка. Його тексти: Пи танне жидівське (1883), Semityzm $i$ antysemityzm w Galicji (1887), Żydzi o kwestji żydowskiej (цикл статей 1893), Радикали і жди (1898), на думку автора, «відображають п'ятнадцятирічний досвід Франка щодо єврейського питання у Галичині кінця XIX століття» (с. 111).

У розділі Іван Франко між ідеологією Теодора Гериеля і Мартіна Бубера представлено філософські погляди Франка, які відзначалися полемічністю стосовно двох питань: проблеми національної держави (репрезентованої поглядами Теодора Герцеля) та філософії діалогу (репрезентованої творчістю Мартіна Бубера). Як і у художній творчості, крізь призму публіцистичних творів та філософування

2 SHKANDRIJ, Myroslav: Jevrei v ukrainskij literaturi. Zobražennia ta identyčnist'. Kyiv: Duch i Litera, 2019, s. 101121. 
Франкове ставлення до євреїв виявляється амбівалентним, полемічним, а інколи і парадоксальним. 3 цього приводу Р.Мних зауважує: «наскільки текст статті містить антиєврейські пасажі, настільки вірш презентує абсолютну ідею співчуття та захисту євреїв» (с. 114). Це унеможливлює, як постійно наголошує автор, однозначність інтерпретацій ані самого Франка, ані єврейських дискурсів у його творчості. Але напевно саме ця амбівалентність, як видно з аналізу значного історіографічного та архівного матеріалів, опрацьованих Р. Мнихом, послужила за життя Франка створенню йому репутації незаангажованого і незалежного критика єврейських течій - асиміляторів та сіоністів, шанованого представниками одних та інших.

Окремо слід відзначити Додатки до монографії, у яких уміщено німецько- та польськомовні публіцистичні праці Івана Франка та тексти сучасників, що спричинилися до дискусії про єврейство ще за життя письменника. У першому додатку зібрані наступні твори Франка: Semityzm i antysemityzm w Galicji, Papiez o morderstwach rytualnych, Żydzi o kwestii żydowskiej, Państwo żydowskie, Jezuityzm w kwestii żydowskiej. (У цьому контексті варто зазначити, що цього року в рамках проекту видання польськомовної спадщини Франка Іваном Матковським та Ігорем Розлуцьким згадані вище есеї Франка стосовно єврейства та ряд інших (Pieśn o uobywatelnieniu Żydów, Kolonizowanie Galicji przez Żydów, Walka o krzyż) були видані у другому томі польськовної публіцистики Iwan Franko. Wkregu

\section{Mgr. Oxana Blaškiv, PhD.}

Instytut Językoznawstwa i Literaturoznawstwa

Uniwersytet Przyrodniczo-Humanistyczny

ul. Stanisława Konarskiego 2, 08-110 Siedlce, Polsko

oksana.blashkiv@uph.edu.p
Rusinów, Polaków i Żydów, що може свідчити про певну готовність українських наукових кіл до наступного кроку на шляху незаангажованого дослідження спадщини Франка ${ }^{3}$ ). До другого та третього додатків увійшли праці Альфреда Носсіга, Яна Фінкельгауса, Теордора Гассе, Маріана Моравського, Саула Рафаеля Ляндау, Яна Будуана-де-Куртене, Василя Щурата, Карпеля Ліппе, Натана Бірнбаума, Гайнріха Моната, та Ісидора Задгера польською та німецькою мовами відповідно. Згадані тексти не завжди легкодоступні, тому зацікавленим дослідникам вони можуть придатися в подальшій роботі не лише над франкознавчою проблематикою, але й тією, що торкається питання єврейства в Галичині та Європі на тлі широких історико-культурних контекстів.

Епіграф до монографії Р. Мниха - «Non indignari, non admirari, sed intelligere» (He зневажати, не захоплюватися, а розуміти) слова нідерландського філософа єврейського походження Баруха Спінози - відображають головну інтенцію автора. Зацікавлений читач також може використати цю тезу як дороговказ для власних неупереджених прочитань спадщини Івана Франка, прочитань, котрі, можна сподіватися, в недалекому майбутньому з'являться в Україні, чи поза її межами. У будь якому разі монографія Романа Мниха Іван Франко і єврейство, що на сьогодні є унікальним і найбільш повним дослідженням цієї проблематики у світовому франкознавсті, уже стала наріжним каменем для подальших наукових пошуків.

3 Iwan Franko. W kręgu Rusinów, Polaków i Żydów. Wybór artykułów ukazujących się w prasie polskojęzycznej pod red. Jana Matkowskiego i Ihora Rozłuckiego. Warszawa-Lwów-Drohobycz-Winnica: Zjednoczenie Nauczycieli Polskich na Ukrainie, 2018, t. 2, s. 464. 